\title{
Global annual methane emission rate derived from its current atmospheric mixing ratio and estimated lifetime
}

\author{
G. R. Sonnemann ${ }^{1,2}$ and M. Grygalashvyly ${ }^{1}$ \\ ${ }^{1}$ Leibniz-Institute of Atmospheric Physics at the University Rostock in Kühlungsborn, Schloss-Str.6, 18225 Ostseebad \\ Kühlungsborn, Germany \\ ${ }^{2}$ Max-Planck-Institute for Solar System Research, Max-Planck-Str. 2, 37191 Katlenburg-Lindau, Germany \\ Correspondence to: M. Grygalashvyly (gryga@iap-kborn.de)
}

Received: 5 September 2013 - Revised: 28 January 2014 - Accepted: 18 February 2014 - Published: 26 March 2014

\begin{abstract}
We use the estimated lifetime of methane $\left(\mathrm{CH}_{4}\right)$, the current methane concentration, and its annual growth rate to calculate the global methane emission rate. The upper and lower limits of the annual global methane emission rate, depending on loss of $\mathrm{CH}_{4}$ into the stratosphere and methane consuming bacteria, amounts to $648.0 \mathrm{Mt} \mathrm{a}^{-1}$ and $608.0 \mathrm{Mt} \mathrm{a}^{-1}$. These values are in reasonable agreement with satellite and with much more accurate in situ measurements of methane. We estimate a mean tropospheric and massweighted temperature related to the reaction rate and employ a mean $\mathrm{OH}$-concentration to calculate a mean methane lifetime. The estimated atmospheric lifetime of methane amounts to 8.28 years and 8.84 years, respectively. In order to improve the analysis a realistic 3D-calculations should be performed.
\end{abstract}

Keywords. Atmospheric composition and structure (geochemical cycles, middle atmosphere - composition and chemistry, troposphere composition and chemistry)

\section{Introduction}

Methane $\left(\mathrm{CH}_{4}\right)$ is an important greenhouse gas and has a warming potential 25 times per molecule larger than that of carbon dioxide $\left(\mathrm{CO}_{2}\right)$. Its atmospheric concentration has more than doubled by anthropogenic impact since the preindustrial time (e.g. Etheridge et al., 1998; Forster et al., 2007; Allan et al., 2007; Kirschke et al., 2013). A large body of publications dealt with the preindustrial methane level (e.g. Rasmussen and Khalil, 1984; Chappellaz et al., 1990; Brook et al., 1996; Etheridge et al., 1998, 2002). The preindustrial level of methane according to Chappellaz et al. (1990), lay at 0.650 ppmv, Etheridge et al. (1998) derived $0.695 \mathrm{ppmv}$, and later Etheridge et al. (2002) increased this value to 0.823 ppmv. Kirschke et al. (2013) stated a mixing ratio of $0.830 \mathrm{ppmv}$ close to that value of Etheridge et al. (2002). Natural variations (increasing for wet and warm periods) also influenced the methane level in the past, so that no constant concentration occurred in the preindustrial time (Rasmussen and Khalil, 1984), but the mixing ratio varied around a mean value. The increase of the methane concentration did stagnate, or it increased very slowly, since the nineties of the past century (e.g. Dlugokencky et al., 2003; Simpson et al., 2006). It increases slightly in present time (e.g. Khalil et al., 2007; Frankenberg et al., 2011). Bergamaschi et al. (2013) found a significant rise of methane and its emission again since 2006 which is, however, essentially smaller than the strong increase in the 20th century. The greatest part of the recent increase is contributed to the tropics and mid-latitude of the Northern Hemisphere (Bergamashi et al., 2013).

The current tropospheric mixing ratio lies between 1.75 and 1.8 ppmv (Krol et al., 1998; Dlugokencky et al., 2003; Frankenberg et al., 2005; Khalil et al., 2007; Frankenberg et al., 2011; Kirschke et al., 2013), after Climate Change 2007: Working Group I: The Physical Science Basis, IPCC Fourth Assessment Report: Climate Change 2007 in 2005 $1774.62 \pm 1.22 \mathrm{ppbv}$. A surface-based monitoring by four networks exhibits very consistent observations. In these networks are involved NOAA (National Oceanic and Atmospheric Administration, Dlugokencky et al., 2011), AGAGE (Advanced Global Atmospheric Gases Experiment, Rigby et al., 2008), CSIRO (Commonwealth Scientific and Industrial Organization, Francey et al., 1999), and UCR (University of California Irvin, Simpson et al., 2012). According to their 
accurate observations the mixing ratio in 2010 amounted to $1799 \pm 2$ ppbv.

There are numerous natural and anthropogenic sources of methane. In the past, various groups try to estimate the contribution of different individual sources. If the lifetime of methane and its concentration in the atmosphere are known then one can calculate the global emission rate.

The lifetime of methane was estimated to range between 8 and 12 years: $10 \pm 2$ years according to Krol et al. (1998); 7.9 years increasing to 8.4 years in 2050 according to Lelieveld et al. (1998); $8.7 \pm 1.3$ years according to the fourth IPCC assessment report (2007); and 9.2 years in the 5th Assessment Report (2011). Prinn et al. (2005) published $9.3(+0.7,-0.6)$ years and Prather et al. (2012) estimated $9.1 \pm 0.9$ years. John et al. (2012) list a survey of estimations about the change in methane lifetime since the preindustrial time. The lifetime can be estimated if the mean hydroxyl $(\mathrm{OH})$ concentration, the tropospheric temperature, and some additional methane sinks are known. The main of additional (secondary) sinks are losses by methane consuming bacteria (5\%) and loss into the stratosphere (7\%) (Reay et al., 2007). Lawrence et al. (2001) used smaller values (1\%) for the loss into the stratosphere. A possible methane sink due to oxidation by atomic chlorine in the marine boundary layer was introduced by Allan et al. (2001, 2007), but its real share in the methane destruction is still under discussion. Other minor sinks are the reactions with other constituents such as $\mathrm{O}\left({ }^{1} \mathrm{D}\right)$, etc.

Prather et al. (2012) estimated for $\tau_{\mathrm{CH}_{4}-\mathrm{OH}}=11.2 \pm$ 1.3 years, for $\tau_{\mathrm{CH}_{4} \text {-bacteria }}=120$ years, for $\tau_{\mathrm{CH}_{4} \text {-strat }}=$ 150 years, and for a possible oxidation by atomic chlorine in the marine atmospheric boundary layer 200 years (according to Allan et al., 2007). For the period 1979-1993 Dentener et al. (2003) calculated for $\tau_{\mathrm{CH}_{4}-\mathrm{OH}}=9.0 \pm 1.3$ years. For the period 1978-2004 Prinn et al. (2005) estimated a lifetime of $10.2(+0.9,-0.7)$ years. A similar value of $10.2 \pm 1.7$ years found Fiore et al. (2009). Other estimations range in the same order: $9.8 \pm 1.6$ years (Vougarakis et al., 2013), $9.9(+1.66$, -1.76 ) years (Stevenson et al., 2006).

The main loss of $\mathrm{CH}_{4}$ in the troposphere is the reaction with $\mathrm{OH}$. $\mathrm{OH}$ reacts with $\mathrm{CH}_{3} \mathrm{CCl}_{3}$ (methyl chloroform $\mathrm{MCF}$ ). The reaction of $\mathrm{OH}$ with methyl chloroform as an efficient radical sink modulating the long-term tropospheric $\mathrm{OH}$ concentration was widely discussed in the literature (e.g. Prinn et al., 1995, 2001; Houweling et al., 1999; Dentener et al., 2003; Krol et al., 2003; Bousquet et al., 2005, 2006; John et al., 2012). In this paper we do not calculate the balance of $\mathrm{OH}$ but use published estimations of $\mathrm{OH}$.

\section{Calculations and results}

The methane lifetime can be estimated via the reaction with $\mathrm{OH}$ by using a globally averaged $\mathrm{OH}$ concentration and considering additional sinks (e.g. Prinn et al.,
2005; Prather et al., 2012; John et al., 2012). The reaction rate of $\mathrm{OH}$ with methane amounts to $r_{1}=2.45 \times$ $10^{-12} \exp (-1775 / T) \mathrm{cm}^{-3} \mathrm{~s}^{-1}$ (Sanders et al., 2006), and rises with increasing temperature. The expression

$\tau_{\mathrm{CH}_{4}}=1 /\left(r_{1} \cdot[\mathrm{OH}]_{\text {mean }}+S\right)$

is the inverse reduced loss term of methane and stands for its lifetime or also called residence-time, where $S$ represents additional sinks. We employ for $S$ values only sinks by bacteria and loss into the stratosphere, published by Reay et al. (2007) and Lawrence et al. (2001) as upper $(5 \%+7 \%)$ and lower $(5 \%+1 \%)$ limit cases, respectively. Note, we take into account only globally averaged values and neglect minor reactions such as a possible reaction with chlorine (Prather et al., 2012). Although the lifetime amounts to approximately a decade, the mixing processes are not fast enough to distribute methane evenly over the whole troposphere. We use a mean temperature ( $\left.T_{\text {mean }}\right)$ related to the temperature acting in the reaction rate. The mass-weighted temperature, with respect to the reaction rate, is somewhat larger than the massweighted tropospheric mean temperature $\left(T_{\text {trop }}\right)$. Taking into account additional sources $S$ in a coefficient $\beta$, the mean lifetime is then

$\tau_{\mathrm{CH}_{4}}=1 /\left(\beta \cdot r_{1}\left(T_{\text {mean }}\right) \cdot[\mathrm{OH}]_{\text {mean }}\right)$

in case where $[\mathrm{OH}]_{\text {mean }}$ is known. The factor $\beta$ amounts to 1.136 and 1.0638 for the additional sinks of $12 \%(5 \%+7 \%)$ and $6 \%(5 \%+1 \%)$, respectively. $T_{\text {mean }}$ is essentially smaller than the global mean surface temperature because $T$ decreases with increasing height.

The mean concentration of $\mathrm{OH}$ derived from several groups listed in Table 1 by Lawrence et al. (2001) is about $[\mathrm{OH}]_{\text {mean }}=10^{6} \mathrm{~cm}^{-3}$. We use a value of $1.16 \times 10^{6} \mathrm{~cm}^{-3}$, according to Spivakovsky et al. (2000). For instance, an $\mathrm{OH}$-concentration close to $1 \times 10^{6} \mathrm{~cm}^{-3}\left(0.973 \times 10^{6} \mathrm{~cm}^{-3}\right)$ follows with a mean reaction related temperature from $\tau_{\mathrm{CH}_{4}-\mathrm{OH}}=11.2$ years (Prather et al., 2012). In the tropics, the $\mathrm{OH}$-concentration is essentially larger than outside of it (Lawrence et al., 2001; Labrador et al., 2004; Kirschke et al., 2013). The non-uniform latitudinal distribution of $\mathrm{OH}$ is one problem in all budget calculations. Equation (2) has a remarkable temperature sensitivity which lies in the order of $2-3 \%$ per $1 \mathrm{~K}(2.5 \%$ per $\mathrm{K}$ for $T=263.5 \mathrm{~K}$, the mean reaction related temperature of the troposphere) and increases with decreasing temperature. The mean mass-weighted tropospheric temperature can be calculated by using the expression

$T_{\text {trop }}=\int_{0}^{12 \mathrm{~km}} T(z) m(z) \mathrm{d} z / \int_{0}^{12 \mathrm{~km}} m(z) \mathrm{d} z$

integrated in the borders of 0 to $12 \mathrm{~km}$, averaged over the whole troposphere. Here $m(z)$ is the mean mass of air per 
cubic centimeter at the height $z$. The mean height of the troposphere ranges coarsely in the order of $12 \mathrm{~km} .50 \%$ of the atmospheric mass lies below $5.5 \mathrm{~km}$, approximately. The mean surface temperature amounts to $T_{\text {surf }}=287.76 \mathrm{~K}$, and the mean lapse rate is $\gamma_{\text {mean }}=6.5 \mathrm{~K} \mathrm{~km}^{-1}$. About $\Delta T=$ $33 \mathrm{~K}$ in the atmosphere corresponds to $1 \mathrm{~km}$ scale height.

$$
\begin{aligned}
& T_{\text {trop }}=\int\left(T_{\text {surf }}-\gamma_{\text {mean }} \cdot z\right) \exp \left(-\frac{z \cdot \Delta T}{T_{\text {surf }}-\gamma_{\text {mean }} \cdot z}\right) \mathrm{d} z / \\
& \int \exp \left(-\frac{z \cdot \Delta T}{T_{\text {surf }}-\gamma_{\text {mean }} \cdot z}\right) \mathrm{d} z \\
& \exp \left(-\frac{1775}{T_{\text {mean }}}\right)=\int \exp \left(\frac{-1775}{T_{\text {surf }}-\gamma_{\text {mean }} \cdot z}\right) \\
& \exp \left(-\frac{z \cdot \Delta T}{T_{\text {surf }}-\gamma_{\text {mean }} \cdot z}\right) \mathrm{d} z / \\
& \int \exp \left(-\frac{z \cdot \Delta T}{T_{\text {surf }}-\gamma_{\text {mean }} \cdot z}\right) \mathrm{d} z
\end{aligned}
$$

It follows that

$$
T_{\text {mean }}=-\frac{1775}{\ln \left(\frac{\int \exp \left(-\frac{1775}{T_{\text {surf }}-\gamma_{\text {mean }} \cdot z}\right) \exp \left(-\frac{z \cdot \Delta T}{T_{\text {surf }}-\gamma_{\text {mean }} \cdot z}\right) \mathrm{d} z}{\int \exp \left(-\frac{z \cdot \Delta T}{T_{\text {surf }}-\gamma_{\text {mean }} \cdot z}\right) \mathrm{d} z}\right)} .
$$

Using these coarse values, the mean mass-weighted temperature of the troposphere amounts to $T_{\text {trop }}=$ $-13.32{ }^{\circ} \mathrm{C}=259.83 \mathrm{~K}$, and the mean reaction rate related temperature is $T_{\text {mean }}=-9.65^{\circ} \mathrm{C}=263.5 \mathrm{~K}$, and correspond to the heights $z\left(T_{\text {trop }}\right)=4.3 \mathrm{~km}$ and $z\left(T_{\text {mean }}\right)=3.58 \mathrm{~km}$, respectively.

We employ the lifetime of methane, the current methane concentration and its growth rate to derive the global methane emission rate $E_{\mathrm{CH}_{4}}$. The balance equation for methane (analogously for other minor constituents) resolved to the emission rate can be written as (e.g. Kirschke et al., 2013; Sonnemann and Grygalashvyly, 2013):

$E_{\mathrm{CH}_{4}}=\frac{\mathrm{d}\left[\mathrm{CH}_{4}\right]}{\mathrm{d} t}+\frac{\left[\mathrm{CH}_{4}\right]}{\tau_{\mathrm{CH}_{4}}}$.

In case of equilibrium $\left(\mathrm{d}\left[\mathrm{CH}_{4}\right] / \mathrm{d} t=0\right)$ the annual emission rate is

$E_{\mathrm{CH}_{4}}=\alpha\left[\mathrm{CH}_{4}\right]_{\text {mix }} H_{\mathrm{eff}} S_{\text {Earth }} / \tau_{\mathrm{CH}_{4}}$,

where $E_{\mathrm{CH}_{4}}$ stands for the global emission rate of methane, $\left[\mathrm{CH}_{4}\right]_{\text {mix }}$ represents the globally averaged tropospheric mixing ratio of methane at about $1.8 \mathrm{ppmv}, H_{\text {eff }}$ means the effective (or mean) density scale height of about $8 \mathrm{~km}(1.033 \mathrm{~kg}$ air in a beam of $1 \mathrm{~cm}^{2}$ at surface area), and $S_{\text {Earth }}$ considers the Earth's surface area of $5.1 \times 10^{18} \mathrm{~cm}^{2}$, and finally $\alpha$ is a factor which converts the mixing ratio given in ppmv into mass in $\mathrm{Mta}^{-1}$. Using the mol volume and the molar mass of methane of $16.04 \mathrm{~g} \mathrm{~mol}^{-1}$ the factor $\alpha=16.04 \times$ $10^{-6} / 22414$.

Figure 1 shows the global methane emission rate for a current atmospheric methane concentration of $1.8 \mathrm{ppmv}$, depending on lifetime including an annual growth rate of methane of $5 \mathrm{ppbva}^{-1}$ and corresponding to an increasing emission of $1.457 \mathrm{Mt} \mathrm{a}^{-1}$. (A methane increase due to a growth rate of $5 \mathrm{ppbv} \mathrm{a}^{-1}$ corresponds to an increase of the warming potential of $0.005 \times 25=0.125 \mathrm{ppmv} \mathrm{CO}_{2}$, coarsely $5 \%$ of the increase due to the annual $\mathrm{CO}_{2}$ growth rate.)

From these values, there follows an annual methane emission rate of $E_{\mathrm{CH}_{4}}=446.66 \mathrm{Mta}^{-1}$ for a lifetime of 12 years, or $538.39 \mathrm{Mta}^{-1}$ for $\tau_{\mathrm{CH}_{4}}=10$ years and for $\tau_{\mathrm{CH}_{4}}=8$ years $672.99 \mathrm{Mta}^{-1}$. Presently there is no equilibrium $\left(\mathrm{d}\left[\mathrm{CH}_{4}\right] / \mathrm{d} t>0\right)$, thus, a correction must be considered. For an annual increase of $10 \mathrm{ppbv}$, according to Eq. (7), the correction amounts to $0.01 \times 524.568 / 1.8=2.914 \mathrm{Mt} \mathrm{a}^{-1}$, ergo the annual emission amounts to $541.3 \mathrm{Mta}^{-1}$ for the 10 year lifetime case.

With the mean tropospheric $\mathrm{OH}$ concentration of Spivakovsky et al. (2000) we get an annual global methane emission rate of $648.0 \mathrm{Mta}^{-1}$ for the first estimation of methane loss $(7 \%)$ into the stratosphere and $608.0 \mathrm{Mt} \mathrm{a}^{-1}$ for the second $(1 \%)$ case. The last value agrees fairly well with model calculations by Lelieveld et al. (1998) who estimated about $600 \mathrm{Mta}^{-1}$. These values are in reasonable $(\approx 10 \%)$ agreement with satellite measurements of methane. The estimated atmospheric lifetime of methane then amounts to 8.28 years and 8.84 years, respectively.

\section{Discussion}

The growth rate varied at around $14 \mathrm{ppbv} \mathrm{a}^{-1}$ before 1990 (Blake and Rowland, 1988; Dlugokencky et al., 1998; Simpson et al., 2002), and it amounts presently to few ppbva ${ }^{-1}$ (van Weele, 2010; Bergamaschi et al., 2013). After a period of decreasing growth rate (partly even negative), the growth rate increased again in 2007 to $8.3 \pm 0.6 \mathrm{ppbva}^{-1}$ (Dlugokencky et al., 2009). But 2007 was an exceptional year, marked among other peculiarities by a strong decrease of the Arctic ice covering and a very warm year over the Siberian wetland. In 2008, the global average increase of methane amounted to $4.4 \pm 0.6 \mathrm{ppbva}^{-1}$ (Dlugokencky et al., 2009) and remained coarsely on this level after this time (Bergamaschi et al., 2013). According to Kirschke et al. (2013) the growth rate amounted to $11.3-12.3 \mathrm{ppbv} \mathrm{a}^{-1}$ in the $1980 \mathrm{~s}, 4.9-6.5 \mathrm{ppbva}^{-1}$ in the 1990s, and 2.3$3.6 \mathrm{ppbva}^{-1}$ in the $2000 \mathrm{~s}$ indicating the slow down of the growth rate. The increase came mainly from the tropical wetland. Obviously, the varying methane growth rates are also connected with global climatic variations. Events such as El Niño, La Niña, or the eruptions of volcano like Mt. Pinatubo and others considerably influence the growth rate. Therefore 


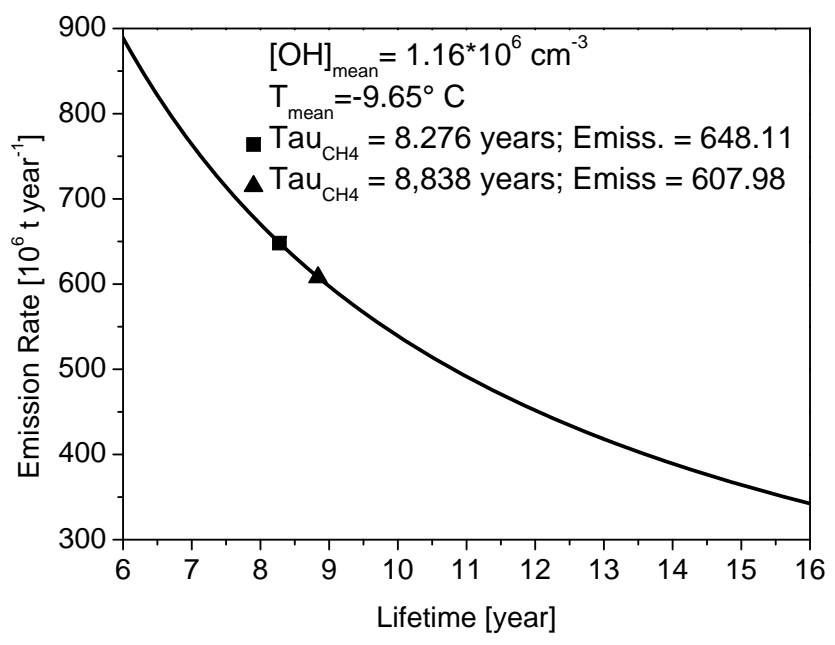

Fig. 1. Global methane emission rate versus lifetime of methane for a current atmospheric methane concentration of $1.8 \mathrm{ppmv}$. This includes an annual growth rate of methane of $5 \mathrm{ppbva}^{-1}$ corresponding to an increasing emission of $1.457 \mathrm{Mt} \mathrm{a}^{-1}$. The lifetime depends inversely on the mean $\mathrm{OH}$ concentration and the tropospheric temperature.

it is not meaningful for the assessment of the methane trend to consider the growth rate of isolated years.

$\mathrm{OH}$ is called the atmosphere cleaner, as it quickly reacts with a large number of environmental pollutants. It determines the atmospheric oxidizing efficiency. $\mathrm{OH}$ is produced by the reaction $\mathrm{O}\left({ }^{1} \mathrm{D}\right)+\mathrm{H}_{2} \mathrm{O} \rightarrow 2 \mathrm{OH}$, and $\mathrm{O}\left({ }^{1} \mathrm{D}\right)$ results from the photolysis of ozone $\left(\mathrm{O}_{3}\right)$. Both methane and ozone are greenhouse gases. An increase of tropospheric ozone reduces the methane concentration. Among other reactions, such as $\mathrm{OH}$ with $\mathrm{CH}_{3} \mathrm{CCl}_{3}$, a sink of $\mathrm{OH}$ is the reaction with $\mathrm{CO}$. The last reaction is included in the smog formation cycle of ozone but in the smog formation cycle itself no hydrogen radical loss takes place. The reactions $\mathrm{CO}+\mathrm{OH} \rightarrow \mathrm{CO}_{2}+\mathrm{H}$ and $\mathrm{H}+\mathrm{O}_{2}+\mathrm{M} \rightarrow \mathrm{HO}_{2}+\mathrm{M}$ are followed by the reaction $\mathrm{NO}+\mathrm{HO}_{2} \rightarrow \mathrm{NO}_{2}+\mathrm{OH}$, which forms back $\mathrm{OH}$, so that the balance of $\mathrm{OH}$ is more intricate as inferred from the pure $\mathrm{OH}$ loss reaction with $\mathrm{CO}$ only. A real loss results from the reaction $\mathrm{NO}_{2}+\mathrm{OH}+\mathrm{M} \rightarrow \mathrm{HNO}_{3}+\mathrm{M}$ forming highly soluble nitric acid $\left(\mathrm{HNO}_{3}\right)$. In the past, the lifetime of methane probably shortened due to an increase of tropospheric ozone and consequently of $\mathrm{OH}$ as well as a slight temperature growth. A small increase in the methane growth rate can be compensated by an adequate decrease of its lifetime.

If using the preindustrial value as the natural level (caused by wetland, termites, methane hydrates, phytoplankton in the ocean (e.g. Sieburth and Donaghay, 1993; Zindler et al., 2013), permafrost soil, and wild animals), the difference should have anthropogenic sources such as livestock, rice cultivation, coaling mining, oil and gas, landfills, biomass burning, waste water, and others. However, natural sources have also been influenced by anthropogenic activities like the reduction of the area of natural wetlands or the impact on the permafrost soil. According to Stern and Kaufmann (1996), a considerable decrease of the natural emission occurred between 1860 and 1990. The decline amounts to roughly a third of its preindustrial value. Van Weele (2010) published values for anthropogenic and natural sources derived from SCIAMACHY onboard the ENVISAT satellite of 395 and $198 \mathrm{Mt} \mathrm{a}^{-1}$ (total $593 \mathrm{Mt} \mathrm{a}^{-1}$ ), respectively. Lelieveld et al. (1998) estimated about $600 \mathrm{Mt} \mathrm{a}^{-1}$, with an anthropogenic share of $70 \%$. Etheridge et al. (1998) derived a value of the global emission rate of $560 \mathrm{Mta}^{-1}$, which tended to stabilize at this level. The budget calculations for the years after 2000 result in a minimum-maximum range of 526569 (mean 548) $\mathrm{Mt} \mathrm{a}^{-1}$ (Kirschke et al., 2013). If summing up all bottom-up emissions they get a value of $678 \mathrm{Mta}^{-1}$ $20 \%$ larger which possibly overestimates individual sources.

Lelieveld et al. (1998) estimated a relatively small lifetime of 7.9 years. A survey of estimated lifetimes of methane due to reactions with $\mathrm{OH}$ can be found in the paper by John et al. (2012). The values range between 9 to 11.2 years. The consideration of other methane sinks yields according to Prather et al. (2012) a lifetime of $9.1 \pm 0.9$ years. The emission rate would agree with satellite measurements for a somewhat smaller mean tropospheric $\mathrm{OH}$-concentration, a cooler mean temperature, or a larger loss by bacteria, by reaction with chlorine and transport into the stratosphere, respectively. However, due to the unequal latitudinal and vertical distribution of methane, hydroxyl and chlorine as well as the transport into the stratosphere a more realistic 3D-calculation could also change the computed emission rate and the lifetimes in certain borders.

The value of the anthropogenic methane emission also agrees fairly well with that value inferred by Stern and Kaufmann (1996), taking into consideration that methane has increased slightly since that time. The SCIAMACHYvalue would agree with our calculations for a lifetime of methane of 9.1 years (close to Prather et al., 2012) and, consequently, with somewhat smaller mean $\mathrm{OH}$-concentrations of $[\mathrm{OH}]_{\text {mean }}=1.055 \times 10^{6} \mathrm{~cm}^{-3}$ or alternatively enhanced secondary methane sinks. Denman et al. (2007) published total emission rates of $582 \pm 87 \mathrm{Mta}^{-1}$ with $60 \%$ anthropogenic share. This value also points to a somewhat larger lifetime.

A small decline of the methane lifetime should result, as previously mentioned, from the increase of tropospheric ozone. An increase of the atmospheric humidity points in the direction of increased $\mathrm{OH}$ formation. A possible increase certainly has different causes than $\mathrm{CO}, \mathrm{NO}_{\mathrm{x}}, \mathrm{H}_{2}$, and MCF, and many other sinks for $\mathrm{OH}$ have also changed in the past. In particular, the increasing $\mathrm{CH}_{4}$ concentration is a sink of $\mathrm{OH}$ resulting in a cumulative feedback (John et al., 2012). Krol et al. (1998) derived a positive $\mathrm{OH}$ trend of most likely $0.46 \% \mathrm{a}^{-1}$. Also John et al. (2012) reported about a small increase of $\mathrm{OH}$ of $3 \% \mathrm{a}^{-1}$. The lifetime of methane decreased due to $\mathrm{OH}$ destruction, according to Krol et al. (1998), from 
9.2 to 8.6 years from 1978 to 1993 . Lelieveld et al. (1998) reported that the lifetime of methane increased by $25-30 \%$ during the past 150 years to the current value of 7.9 years, and will further increase by about $6 \%$ until 2050 , then reaching 8.4 years. Note that both the production and the sinks have changed in the past, so it is not justified to extrapolate a trend found for a limited interval.

\section{Conclusions}

A precise knowledge of the lifetime and the mixing ratio of methane are the preconditions to calculate its annual emission rate. The published range of uncertainty amounts to $\pm 20 \%$. If the emission rate is known, one can split the sum into the partial emission rates of the individual natural and anthropogenic sources. The reason for a slowdown (or stop) of the methane increase can result from a reduced growth rate of methane and/or from a reduction of the methane lifetime due to an increase of $[\mathrm{OH}]$ and/or warming of the atmosphere, compensating the growth rate of emission and/or other impacts on the loss term.

The estimations are, of course, relatively coarse. A 3Dcalculation taking into account the real global distribution of the temperature and the estimated $\mathrm{OH}$-concentration depending on latitude, height and local time could improve the accuracy of this estimation. Due to the high temperature sensitivity of the $\mathrm{OH}-\mathrm{CH}_{4}$-reaction rate the consideration of the real temperature decreasing with altitude is rather important. A global methane emission rate of $648.0 \mathrm{Mta}^{-1}$ and $608.0 \mathrm{Mta}^{-1}(7 \%$ and $1 \%$ methane loss into the stratosphere, respectively) and a mean methane lifetime of $\sim 8.28$ and 8.84 years result from our analysis of the present atmospheric concentrations of methane, mean tropospheric $\mathrm{OH}$, and the percentage share of the secondary methane sinks.hack

Topical Editor P. Drobinski thanks one anonymous referee for his/her help in evaluating this paper.

The service charges for this open access publication have been covered by the Max Planck Society.

\section{References}

Allan, W., Lowe, D. C., and Cainey, J. M.: Active chlorine in the remote marine boundary layer: Modeling anomalous measurements of $\delta^{13} \mathrm{C}$ in methane, Geophys. Res. Lett., 28, 3239-3242, 2001.

Allan, W., Struthers, H., and Lowe, D. C.: Methane carbon isotope effects caused by atomic chlorine in the marine boundary layer: Global model results compared with Southern Hemisphere measurements, J. Geophys. Res., 112, D04306, doi:10.1029/2006JD007369, 2007.

Bergamaschi, P., Houweling, S., Segers, A., Krol, M., Frankenberg, C., Scheepmaker, R. A., Dlugokencky, E., Wofsy, S. C., Kort, E. A., Sweeney, C., Schuk, T., Brenninkmmeijer, Chen, H., Beck, V., and Gerbig, C.: Atmospheric $\mathrm{CH}_{4}$ in the first decade of the 21st century: Inverse modeling analysis using SCIAMACHY satellite retrievals and NOAA surface measurements, J. Geophys. Res., 118, 7350-7369, doi:10.1002/jgrd.50480, 2013.

Blake, D. R. and Rowland F. S.: Continuing world-wide increase in tropospheric methane, 1978-1987, Science, 239, 1129-1131, 1988.

Bousquet, P., Hauglustaine, D. A., Peylin, P., Carouge, C., and Ciais, P.: Two decades of $\mathrm{OH}$ variability as inferred by an inversion of atmospheric transport and chemistry of methyl chloroform, Atmos. Chem. Phys., 5, 2635-2656, doi:10.5194/acp-52635-2005, 2005.

Bousquet, P., Ciais, P., Miller, J. B., Dlugokencky, E. J., Hauglustaine, D. A., Prigent, C., Van der Werf, G. R., Peylin, P., Brunke, E. G., Carouge, C., Langenfels, R. L., Lathiere, J., Papa, F., Ramonet, M., Schmidt, M., Steele, L. P., Tyler, S. C., and White, J.: Contribution of anthropogenic and natural sources to atmospheric methane variability, Nature, 443, 439-443, 2006.

Brook, E. J., Sowers, T., and Orchado, J.: Rapid variations in atmospheric methane concentration during past 110,000 years, Science, 273, 1087-1091, 1996.

Chappellaz, J., Barnola, J. M., Raynaud, D., Korotkevich, Y. S., and Lorius, C.: Ice-Core Record of Atmospheric Methane over the Past 160,000 Years, Nature, 345, 127-131, doi:10.1038/345127a0, 1990.

Denman, K. L., Brasseur G., Chidthaisong, A.,Ciais, P., Cox, P. M., Dickenson, R. E., Heinze, C., Holland, E., Jacob, D. J., Lohmann, U., Ramachandran, S., da Silva Dias, P. L., Wofsy, S. C., and Zhang, X.: Couplings between changes in the climate system and biochemistry, in: Climate Change 2007: The Physical Science Basis. Contribution of Working Group I to the Fourth Assessment Report of the Intergovernmental Panel on Climate Change, edited by: Solomon, S., Qin, D., Manning, M., Chen, Z., Marquis, M., Averyt, K. B., Tignor, M., and Miller, H. L., Cambridge University Press, Cambridge UK and New York, NY, USA, 499587, 2007.

Dentener, F., Peters, W., Krol, M., van Weele, Bergamaschi, P., and Lelieveld, J.: Inter-annual variability and trend of $\mathrm{CH}_{4}$ lifetime as a measure for OH change in the 1979-1993 time period, J. Geophys. Res., 108, 4442, doi:10.1029/2002JD002916, 2003.

Dlugokencky, E. J., Masarie, K. A., Lang, P. M., and Tans, P. P.: Continuing decline in the growth rate of the atmospheric methane burden, Nature, 393, 447-450, doi:10.1038/30934, 1998.

Dlugokencky, E. J., Houweling, S., Bruhwiler, L., Masarie, K. A., Lang, P. M., Miller, J. B., and Tans, P. P.: Atmospheric methane levels off: Temporary pause or a new steady-state?, Geophys. Res. Lett., 30, 1992, doi:10.1029/2003GL018126, 2003.

Dlugokencky, E. J., Bruhwiler, L., White, J. W. C., Emmons, L. K., Novelli, P. C., Montzka, S. A., Masarie, K. A., Lang, P. M., Crotwell, A. M., Miller, J. B., and Gatti, L. V.: Observational constraints on recent increases in the atmospheric $\mathrm{CH}_{4}$ burden, Geophys. Res. Lett., 36, L18803, doi:10.1029/2009GL039780, 2009.

Dlugokencky, E. J., Nisbet, E. G., Fisher, R., and Lowry, D.: Global atmospheric methane: budget change and dangers, Philos. T. Roy. Soc. A, 369, 2058-2072, 2011.

Etheridge, D. M., Steele, L. P., Francey, R. J., and Langenfelds, R. L.: Atmospheric methane between 1000 A.D. and present: Evidence of anthropogenic emissions climatic variability, J. Geophys. Res., 103, 15979-15993, 1998. 
Etheridge, D. M., Pearman, G. I., and Fraser, P. J.: Change in the tropospheric methane between 1841 and 1978 from a high accumulation-rate Antarctic ice core, Wiley Online Library, doi:10.1034/j.1600-0889.1992.t01-3-00006.x, 2002.

Fiore, A. M., Dentener, F. J., Wild, O., Cuvelier, C., Schultz, M. G., Hess, P., Textor, C., Schulz, M., Doherty, R. M., Horowitz, L. W., MacKenzie, I. A., Sanderson, M. G., Shindell, D. T., Stevenson, D. S., Szopa, S., Van Dingenen, R., Zeng, G., Atherton, C., Bergmann, D., Bey, I., Carmichael, G., Collins, W. J., Duncan, B. N., Faluvegi, G., Folberth, G., Gauss, M., Gong, S., Hauglustaine, D., Holloway, T., Isaksen, I. S. A., Jacob, D. J., Jonson, J. E., Kaminski, J. W., Keating, T. J., Lupu, A., Marmer, E., Montanaro, V., Park, R. J., Pitari, G., Pringle, K. J., Pyle, J. A., Schroeder, S., Vivanco, M. G., Wind, P., Wojcik, G., Wu, S., and Zuber, A.: Multimodel estimates of intercontinental sourcereceptor relationships for ozone pollution, J. Geophys. Res., 114, D04301, doi:10.1029/2008JD010816, 2009.

Forster, P., Ramaswarmy, V., Artaxo, P., Berntsen, T., Betts, R., Fahey, D. W., Haywood, J., Lean, J., Lowe, D. C., Myhre, G., Nganga, J., Prinn, R., Raga, G., Schulz, M., and Van Dorland, R.: Changes in atmospheric constituents and in radiative forcing, in: Climate Change 2007, edited by: Solomon, S., Qin, D., Manning, M., Chen, Z., Marquis, M., Averyt, K. B., Tignor, M., and Miller, H. L., Cambridge University Press, Cambridge, UK and New York, NY, USA, 129-234, 2007.

Francey, R. J., Steele, L. P., Langenfelds, R. L., and Pak, B. C.: High-precision long-term monitoring of relatively active and related trace gases at surface sites and from aircraft in the southern hemisphere atmosphere, J. Atmos. Sci., 56, 278-285, 1999.

Frankenberg, C., Meirink, J. F., van Weele, M., Rasmussen, R. K., Platt, U., and Wagner, T.: Assessing methane emission from global spaceborne observations, Science, 308, 1010-1014, doi:10.1126/science.1106644, 2005.

Frankenberg, C., Aben, I., Bergamaschi, P., Dlugokencky, E. J., van Hees, R., Houweling, S., van der Meer, P., Snel, R., and Tol, P.: Global column-averaged methane mixing ratios from 2003 to 2009 as derived from SCIAMACHY: Trends and variability, J. Geophys. Res., 116, D04302, doi:10.1029/2010JD014849, 2011.

Houweling, S., Kaminsky, T., Dentener, F., Lelieveld, J., and Heinmann, M.: Inverse modelling of methane sources and sinks using adjoint of a global transport model, J. Atmos. Res., 104, $26137-$ 26160, 1999.

IPCC Fourth Assessment Report: Climate Change, 2007.

IPCC Fifth Assessment Report: Renewable Energy Sourcesand Climate Change Mitigation (AR5), 2011.

John, J. G., Fiore, A. M., Naik, V., Horowitz, L. W., and Dunne, J. P.: Climate versus emission drivers of methane lifetime against loss by tropospheric OH from 1860-2100, Atmos. Chem. Phys., 12, 12021-12036, doi:10.5194/acp-12-12021-2012, 2012.

Khalil, M. A. K., Butenhoff, C. L., and Rasmussen, R. A.: Atmospheric Methane: Trends and Cycles of Sources and Sinks, Environ. Sci. Technol., 41, 2131-2137, 2007.

Kirschke, S., Bousquet, P., Ciais, P., Marielle Saunois, M., Canadell, J. G., Dlugokencky, E. J., Bergamaschi, P., Bergmann, D., Blake, D. R., Bruhwiler, L., Cameron-Smith, P., Castaldi, S., Chevallier, F., Feng, L., Fraser, A., Fraser, P. J., Heimann, M., Hodson, E. L., Houweling, S., Josse, B., Krummel, P. B., Lamarque, J.F., Langenfelds, R. L., Le Quéré, C., Naik, V., O’Doherty, S., Palmer, P. I., Pison, I., Plummer, D., Poulter, B., Prinn, R. G.,
Rigby, M., Ringeval, B., Santini, M., Schmidt, M., Shindell, D. T., Simpson, I. J., Spahni, R., Steele, L. P., Strode, S. A., Sudo, K., Szopa, S., van der Werf, G. R., Voulgarakis, A., van Weele, M., Weiss, R. F., Williams, J. E., and Zeng, G.: Three decades of global methane sources and sinks, Nat. Geosci., 8, 813-823, doi:10.1038/NGEO1955, 2013.

Krol, M. and Lelieveld, J.: Can the variability of tropospheric $\mathrm{OH}$ be deduced from measurements of 1,1,1trichloroethane (methyl chloroform)?, J. Geophys. Res., 108, 4125, doi:10.1029/2002JD002423, 2003.

Krol, M., van Leeuwen, P. J., and Lelieveld, J.: Global OH trend inferred from methylchloroform measurements, J. Geophys. Res., 103, 10697-10711, doi:10.1029/98JD00459, 1998.

Labrador, L. J., von Kuhlmann, R., and Lawence, M. G.: Strong sensitivity of the global mean $\mathrm{OH}$ concentration and the tropospheric oxidizing efficiency to the source of $\mathrm{NO}_{\mathrm{x}}$ from lightening, Geophys. Res. Lett., 31, L06102, doi:10.1029/2003GL019229, 2004.

Lawrence, M. G., Jöckel, P., and von Kuhlmann, R.: What does the global mean $\mathrm{OH}$ concentration tell us?, Atmos. Chem. Phys., 1, 37-49, doi:10.5194/acp-1-37-2001, 2001.

Lelieveld, J., Crutzen, P. G., and Dentener, F. G.: Changing concentration, lifetime and climate forcing of atmospheric methane, Tellus B, 50, 128-150, doi:10.1034/j.1600-0889.1998.t01-100002.x, 1998.

Prather, M. J., Holmes, C. D., and Hsu, J.: Reactive greenhouse gas scenarios: Systematic exploration of uncertainties and the role of atmospheric chemistry, Geophys. Res. Lett., 39, L09803, doi:10.1029/2012GL051440, 2012.

Prinn, R. G., Weiss, R. F., Miller, B. R., Huang, J., Alyea, F. N., Cunnold, D. M., Fraser, P. J., Hartley, D. E., and Simmonds, P. G.: Atmospheric trends and lifetime of $\mathrm{CH}_{3} \mathrm{CCl}_{3}$ and global $\mathrm{OH}$ concentrations, Science, 269, 187-192, 1995.

Prinn, R. G., Huang, J., Weiss, R. F., Cunnold, D. M., Fraser, P. J., Simmonds, P. G., McCulloch, A., Harth, C., Salameh, P., O’Doherty, S., Wang, R. H. J., Porter, L., and Miller, B. R.: Evidence for substantial variations of atmospheric hydroxyl radicals in the past two decades, Science, 293, 1882-1888, doi:10.1126/science.1058673, 2001.

Prinn, R. G., Huang, J., Weiss, R. F., Cunnold, D. M., Fraser, P. J., Simmonds, P. G., McCulloch, A., Harth, C., Reimann, S., Salameh, P., O’Doherty, S., Wang, R. H. J., Porter, L. W., Miller, B. R., and Krummel, P. B.: Evidence for variability of atmospheric hydroxyl radicals over the past quarter century, Geophys. Res. Lett., 32, L07809, doi:10.1029/2004GL022228, 2005.

Rasmussen, R. A. and Khalil, M. A. K.: Atmospheric methane in recent and ancient atmospheres: concentrations, trends, and interhemispheric gradient, J. Geophys. Res., 89, 11599-11605, 1984.

Reay, D., Hewitt, C. N., Smith, K., and Grace, J.: Greenhouse Gas Sinks, CABI, Oxfordshire, 2007.

Rigby, M., Prinn, R. G., Fraser, P. J., Simmonds, P. G., Langenfelds, R. L., Huang, J., Cunnold, D. M., Steele, L. P., Krummel, P. B., Weiss, R. F., O'Doherty, S., Salameh, P. K., Wang, H. J., Harth, C. M., Mühle, J., and Porter, L. W.: Renewed growth of atmospheric methane, Geophys. Res. Lett., 35, L22805, doi:10.1029/2008GL036037, 2008.

Sander, S. P., Friedl, R. R., Golden, D. M., Kurylo, M. J., Huie, R. E., Orkin, V. L., Moortgat, G. K., Wine, P. H., Ravishankara, A. R., Kolb, C. E., Molina, M. J., and Finlayson-Pitts, B. J.: Chemical kinetics and photochemical data for use in stratospheric mod- 
eling, JPL Publication 06-2, Evaluation Number 15, California Insitute of Technology, Pasadena, California, USA, 2006.

Sieburth, J. McN. and Donaghay, P. L.: Planctonic methane production and oxidation within in the algal maximum of the pycnocline: seasonal fine-scale observations in an anoxic estuarine basin, Marine Ecology Progress Series, 100, 3-15, 1993.

Simpson, I. J., Blake, D. R., Rowland, F. S., and Chen, T.-Y.: Implications of the recent fluctuations in the growth rate of tropospheric methane, Geophys. Res. Lett., 29, 117.1-117.4, doi:10.1029/2001GL014521, 2002.

Simpson, I. J., Rowland, F. S., Meinardi, S., and Blake, D. R.: Influence of biomass burning during recent fluctuations in the slow growth of global tropospheric methane, Geophys. Res. Lett., 33, L22808, doi:10.1029/2006GL027330, 2006.

Simpson, I. J., Andersen, M. P. S., Meinardi, S., Bruhwiler, L., Blake, N. J., Helmig, D., Rowland, F. S., and Blake, D. R.: Longterm decline of global atmospheric ethane concentrations and implications for methane, Nature, 488, 490-494, 2012.

Sonnemann, G. R. and Grygalashvyly, M.: Effective $\mathrm{CO}_{2}$ lifetime and future $\mathrm{CO}_{2}$ levels based on fit function, Ann. Geophys., 31, 1591-1596, doi:10.5194/angeo-31-1591-2013, 2013.

Spivakovsky, C. M., Logan, J. A., Montzka, S. A., Balkanski, Y. J., Foreman-Fowler, M., Jones, D. B. A., Horowitz, L. W., Fusco, A. C., Brenninkmeijer, C. A. M., Prather, M. J., Wofsy, S. C., and McElroy, M. B.: Three-dimensional climatological distribution of tropospheric OH: Update and evaluation, J. Geophys. Res., 105, 8931-8980, 2000.

Stern, D. I. and Kaufmann, R. K.: Estimates of global anthropogenic methane emissions 1860-1993, Chemosphere, 33, 159176, 1996.
Stevenson, D. S., Dentener, F. G., Schultz, M. G., Ellingsen, K., van Noije, T. P. C., Wild, O., Zeng, G., Amann, M., Atherton, C. S., Bell, N., Bergmann, D. J., Bey, I., Butler, T., Cofala, J., Collins, W. J., Derwent, R. G., Doherty, R. M., Drevet, J., Eskes, H. J., Fiore, A. M., Gauss, M., Hauglustaine, D. A., Horowitz, L. W., Isaksen, I. S. A., Krol, M. C., Lamarque, J.-F., Lawrence, M. G., Montanaro, V., Müller, J.-F., Pitari, G., Prather, M. J., Pyle, J. A., Rast, S., Rodriguez, J. M., Sanderson, M. G., Savage, N. H., Shindell, D. T., Strahan, S. E., Sudo, K., and Szopa, S.: Multimodel ensemble simulations of present-day and near future tropospheric ozone, J. Geophys. Res. Atmos., 111, D08301, doi:10.1029/2005JD006338, 2006.

van Weele M.: Assessing methane emissions from global spaceborne observations, report: Koninklijk Nederlands Meteorologisch Institut Ministerie van Infrastructuur en Millieu, 2010.

Voulgarakis, A., Naik, V., Lamarque, J.-F., Shindell, D. T., Young, P. J., Prather, M. J., Wild, O., Field, R. D., Bergmann, D., CameronSmith, P., Cionni, I., Collins, W. J., Dalsøren, S. B., Doherty, R. M., Eyring, V., Faluvegi, G., Folberth, G. A., Horowitz, L. W., Josse, B., MacKenzie, I. A., Nagashima, T., Plummer, D. A., Righi, M., Rumbold, S. T., Stevenson, D. S., Strode, S. A., Sudo, K., Szopa, S., and Zeng, G.: Analysis of present day and future $\mathrm{OH}$ and methane lifetime in the ACCMIP simulations, Atmos. Chem. Phys., 13, 2563-2587, doi:10.5194/acp-13-25632013, 2013.

Zindler, C., Bracher, A., Marandino, C. A., Taylor, B., Torrecilla, E., Kock, A., and Bange, H. W.: Sulphur compounds, methane, and phytoplankton: interactions along a north-south transit in the western Pacific Ocean, Biogeosciences, 10, 3297-3311, doi:10.5194/bg-10-3297-2013, 2013. 